\title{
Strategi Self-Regulated Learning dalam Meningkatkan Prestasi Belajar Matematika pada Siswa SMP
}

\author{
Prima Soraya Anas ${ }^{1} \mathcal{E}$ Asmadi Alsa ${ }^{2}$ \\ Fakultas Psikologi Universitas Gadjah Mada
}

\begin{abstract}
This research aims to determine the relationship between self-regulated learning and mathematics achievement in junior high school students. The dependent variable in this research is mathematics achievement which is measured using the mid-term examination. The independent variable is self-regulated learning measured using a scale of self-regulated learning developed based on Zimmerman's theory (1989). Hypothesis was there is positive relationship between self-regulated learning and mathematics achievement. Subjects were 129 grade VIII students of SMP Negeri X in the year of 2016/2017. Data was analysed using Pearson's product-moment correlation technique. Results showed that there is a significant positive relationship between self-regulated learning and mathematics achievement, $\mathrm{r}=0.351(\mathrm{p}<0.01)$. As a conclusion, the hypothesis was accepted.
\end{abstract}

Keywords: junior high school' students; mathematics achievement; self-regulated learning

\begin{abstract}
Abstrak. Penelitian ini bertujuan untuk mengetahui hubungan antara self-regulated learning dengan prestasi belajar matematika. Variabel dependen dalam penelitian ini adalah prestasi belajar matematika yang diukur dengan nilai UTS matematika. Variabel independen dalam penelitian ini adalah self-regulated learning diukur menggunakan skala self-regulated learning mengacu pada teori Zimmerman (1989). Hipotesis yang diajukan dalam penelitian ini adalah "terdapat hubungan positif antara self-regulated learning dengan prestasi belajar matematika." Subjek dalam penelitian ini berjumlah 129 siswa kelas VIII SMP Negeri X tahun ajaran 2016/2017. Metode analisis data yang digunakan yaitu teknik korelasi product moment dari Pearson. Hasil analisis data dalam penelitian ini menunjukkan bahwa terdapat korelasi positif yang signifikan antara self-regulated learning dengan prestasi belajar matematika, dengan $r=0,351$ dan $p<0,01$, sehingga hipotesis dapat diterima.
\end{abstract}

Kata Kunci: prestasi belajar matematika; self-regulated learning; siswa SMP

Keberhasilan dalam dunia pendidikan dapat dilihat dari hasil prestasi belajarnya. Menurut Hamdu dan Agustina (2011) prestasi belajar merupakan sebuah

\footnotetext{
${ }^{1}$ Korespondensi mengenai isi artikel ini dapat dilakukan melalui: prima.soraya.a@mail.ugm.ac.id 22Atau melalui asmalsa@ugm.ac.id
}

pencapaian atau tingkat keberhasilan seseorang dalam memahami suatu pelajaran yang dinyatakan dalam bentuk nilai setelah mengalami proses belajar mengajar. Prestasi belajar menjadi ujung dari proses belajar mengajar yang berguna untuk mengukur kemampuan siswa 
dalam menguasai materi, termasuk di dalamnya adalah bidang matematika.

Penelitian yang dilakukan oleh Wager (2013) menemukan bahwa seseorang yang berhasil dalam bidang matematika akan mengalami kesuksesan pula dalam bidang lainnya. Secara tidak langsung kesuksesan dalam bidang matematika akan menjadi prediktor kesuksesan di bidang lainnya. Pentingnya disiplin ilmu matematika ini dijadikan syarat kelulusan termasuk siswa SMP/ MTs di Indonesia. Pencapaian yang didapat siswa pada mata pelajaran matematika, menjadi salah satu penentu kelulusan siswa pada UN. Kondisi ini menjadi tantangan bagi siswa agar dapat lulus ke jenjang pendidikan selanjutnya.

Kenyataannya masih banyak siswa yang memiliki prestasi belajar matematika yang rendah. Hal ini dibuktikan dengan hasil UN matematika siswa SMP/MTs tahun 2011 di Provinsi Bangka Belitung, ada sebanyak 332 siswa yang tidak lulus. Penyebab tidak lulusnya siswa, dikarenakan anjloknya nilai matematika. Hasil Ujian Nasional tahun 2015 di Provinsi NTT menunjukkan bahwa nilai rata-rata matematika siswa SMP memiliki nilai yang paling rendah apabila dibandingkan dengan nilai mata ujian lain (Pukan, 2015). Pada tahun 2012 hasil UN tingkat SMP menunjukkan bahwa matematika merupakan penyebab paling tinggi dalam ketidaklulusan siswa secara nasional (Anna, 2012). Tahun 2016 hasil rata-rata ujian nasional SMP/MTs secara nasional menurun 3 poin dari tahun 2015. Nilai matematika tercatat sebagai nilai yang terkoreksi paling besar dibandingkan mata pelajaran lainnya, yaitu terjadi penurunan rerata nilai 6,04 poin (Wurinanda, 2016). Selain itu, rendahnya prestasi belajar matematika siswa SMP di Indonesia diperlihatkan dengan rendahnya pencapaian pada survei TIMSS (Trends in International
Mathematics and Science Study) dan PISA (Programme for International Study Asessment) setiap lima tahun sekali. Hal ini dibuktikan dengan hasil survei TIMSS pada tahun 1999 Indonesia memperoleh skor 403 dan berada di peringkat 34 dari 38. Tahun 2003 Indonesia memperoleh skor 411 dan berada di peringkat 35 dari 46. Tahun 2007 Indonesia menduduki peringkat 36 dari 49 dengan perolehan skor 397. Selanjutnya, tahun 2011 Indonesia mengalami penurunan dari tahun-tahun sebelumnya yaitu memperoleh skor 386, berada di peringkat 38 dari 42 (nces.ed.gov/survey/timss, 2011). Survei TIMSS terakhir tahun 2015 prestasi matematika siswa Indonesia masih tergolong rendah dibandingkan Negara lainnya. Perolehan skor yang didapat yaitu 397 dan berada di peringkat bawah yaitu 45 dari 50 negara (Rahmawati, 2016). Hasil survei PISA juga menunjukkan hal yang sama. Indonesia berada pada peringkat bawah dibandingkan negara lainnya. Survei PISA pada tahun 2000 Indonesia berada diposisi 39 dari 41 negara dengan skor 367. Tahun 2003 Indonesia berada diurutan 38 dari 40 negara. Tahun 2006 berada di posisi 50 dari 57 negara dengan perolehan skor 391. Tahun 2012 Indonesia berada di urutan kedua terakhir yang diikuti oleh 65 negara dengan perolehan skor 375. Survei PISA tahun 2015 Indonesia masih menduduki posisi dibawah yaitu peringkat 66 dari 72 negara dengan perolehan skor 386 (PISA, 2015). Berdasarkan data survei internasional tersebut, Indonesia masih tertinggal jauh dengan negara-negara lainnya dan selalu di urutan bawah (NCES, 2011).

Prestasi belajar yang rendah disebabkan oleh adanya faktor-faktor yang kurang berfungsi optimal. Kleden (2016) menyampaikan bahwa penyebab prestasi matematika di Indonesia rendah di antaranya adalah banyak siswa di 
Indonesia yang tidak menyenangi matematika. Siswa belum merasa matematika penting bagi kehidupan sehari-hari. Matematika juga dianggap sebagai pelajaran yang menakutkan dan menyebalkan. Siswa sudah terlanjur membentuk di dalam pikirannya bahwa matematika adalah mata pelajaran yang sulit. Guru matematika di sekolah juga masih menggunakan metode pembelajaran yang kurang tepat bagi siswanya. Menurut Armanto (2002) apabila guru melaksanakan pembelajaran secara konvensional atau metode ceramah siswa akan menjadi pasif. Pembelajaran seperti itu tidak membantu siswa mengembangkan kemampuannya dalam pemecahan masalah, penalaran, koneksi, dan komunikasi matematis. Akibatnya kemampuan kognitif tingkat tinggi siswa menjadi lemah. Lebih lanjut, hasil seminar TIMSS 2015 menyebutkan bahwa salah satu penyebab prestasi matematika Indonesia rendah karena persepsi diri yang negatif. Persepsi diri negatif pada pelajaran matematika membuat mereka enggan dan menghindar dalam belajar matematika. Menurut hasil survey TIMSS hanya $23 \%$ siswa di Indonesia yang percaya diri memiliki kemampuan di bidang matematika. Persentase ini relatif rendah dibandingkan dengan negaranegara lainnya (Rahmawati, 2016).

Menurut Zimmerman dan MartinezPons (1990) faktor internal yang dapat memengaruhi prestasi belajar siswa adalah regulasi diri dalam belajar atau diistilahkan self-regulated learning. Ketika siswa memiliki prestasi yang tinggi, artinya secara internal ia telah melakukan pengelolaan diri yang lebih baik daripada siswa yang memiliki prestasi rendah. Siswa yang memiliki regulasi diri yang baik, mereka akan aktif menggunakan kemampuan akademiknya, seperti telah menetapkan tujuan, memilih dan menyusun strategi, dan memonitor dirinya sediri dalam aktivitas belajar (Zimmerman, 2008). Hal senada juga diungkapkan oleh Pintrich (2000) yaitu self-regulated learning merupakan proses belajar yang aktif dimana siswa telah menetapkan tujuan, kriteria, dan standar belajarnya, setelah itu mereka berusaha untuk memonitor proses, mengatur, dan mengontrol aspek kognisi, motivasi, dan perilakunya setiap waktu serta membuat lingkungannya dapat mendukung proses belajarnya. Self-regulated learning berperan membantu siswa dalam menetapkan target akademis, meningkatkan persepsi kemampuan akademik dan mengendalikan aktivitas belajarnya (Montalvo \& Torres, 2004). Hasil penelitian Rosario, Nunez, Valle, Pienda, dan Lourenco (2013) memperlihatkan bahwa ada hubungan positif antara siswa yang memiliki strategi self-regulated learning dengan prestasi belajar matematika. Siswa yang dapat mengorganisasikan, mengatur dan lebih mempersiapkan tugasnya, serta melakukan perencanaan belajarnya dengan baik akan memengaruhi perolehan prestasi matematikanya.

Peneliti melakukan wawancara di SMP Negeri " $X$ " di Bantul pada tanggal 01 Agustus 2016 dengan guru matematika dan dua siswa kelas VIII. Dari hasil wawancara tersebut, didapatkan beberapa informasi yang mendukung pendapat yang telah dipaparkan di atas. Berdasarkan hasil wawancara pada dua siswa menunjukkan bahwa siswa sudah membentuk di dalam pikirannya kalau matematika adalah pelajaran yang sulit. Selain itu, didapatkan informasi bahwa siswa juga kurang menyukai pelajaran matematika. Selanjutnya, hasil wawancara dengan guru menunjukkan bahwa siswa 
yang dapat mengatur perilaku belajar matematika, memperoleh prestasi belajar matematika yang baik. Sebaliknya, siswa yang kurang bisa mengendalikan dan mengatur perilaku belajarnya, mendapatkan prestasi belajar matematika yang kurang memuaskan. Lebih lanjut, nilai Kriteria Ketuntasan Minimal (KKM) pelajaran matematika di sekolah ini adalah 72. Hal ini memperlihatkan bahwa nilai KKM matematika yang ditetapkan di SMP Negeri " $X$ " masih di bawah target ketuntasan secara nasional (Permendiknas, 2015) menetapkan target ketuntasan secara nasional adalah 75). Kenyataannya dengan KKM yang masih berada di bawah target yang diharapkan secara nasional masih ada sebanyak 38,13\% siswa kelas VIII yang masih mendapatkan nilai di bawah KKM.

Penelitian yang dilakukan oleh Ahmed, Werf, Kuyper, dan Minnaert (2013) mengenai hubungan emosi dan selfregulated learning dengan prestasi matematika menunjukkan bahwa ketika seseorang dalam emosi positif, ia akan melakukan self-regulated learning dengan baik. Self-regulated learning ini yang akan berpengaruh pada prestasi belajar matematika siswa. Siswa yang mampu melakukan pengelolaan diri dalam belajarnya dengan baik akan berdampak pada prestasi matematika tinggi. Hasil penelitian ini menyatakan bahwa terdapat korelasi positif yang signifikan antara selfregulated learning dengan prestasi belajar matematika.

Penelitian yang dilakukan oleh Latifah (2010) menunjukkan bahwa seorang self-regulated learner mengambil tanggung jawab terhadap kegiatan belajar mereka. Mereka mengambil alih otonomi untuk mengatur dirinya serta menetapkan tujuan dan masalah-masalah yang mungkin dihadapinya dalam mencapai tujuan-tujuannya, mengembangkan standar tingkat kesempurnaan dalam pencapaian tujuan dan mengevaluasi cara yang paling baik untuk mencapai tujuannya. Mereka dapat mengoreksi kesalahannya serta mengarahkan kembali dirinya ketika perencanaan yang dibuatnya tidak sesuai. Menurut Zimmerman dan Martinez-Pons (dalam Latifah, 2010) hal tersebut terbukti sangat efisien untuk meningkatkan prestasi belajar.

Penelitian Hani (2010) menunjukkan bahwa siswa SMP yang diberi pelatihan strategi self-regulated learning dalam belajar matematika menunjukkan adanya peningkatan prestasi belajar matematika. Penelitian dilakukan pada siswa SMP swasta di Yogyakarta dengan cara siswa diberi pelatihan berupa menyusun tujuan, memiliki target waktu pencapaian dan menggunakan strategi belajar yang tepat. Penetapan tujuan disertai dengan hasil belajar yang telah dicapai sehingga mereka bisa menentukan performansi mereka saat ini. Setelah mendapatkan pelatihan seperti yang telah dijelaskan di atas, siswa dapat menentukan tujuannya lebih spesifik sehingga mereka dapat lebih mudah dalam mencapainya. Mereka juga memonitor pencapaian hasil belajar berdasarkan umpan balik (nilai, masukan dari guru \& teman) yang mereka dapatkan agar lebih baik, dengan demikian mereka dapat mengevaluasi strategi yang efektif dan searah dengan pencapaian target akademis yang ditetapkan. Hasil penelitian tersebut memperlihatkan bahwa siswa yang diberi pelatihan selfregulated learning dalam belajar matematika mengalami peningkatan pada prestasi belajar matematikanya. Menurut Uno (2009) siswa yang ikut terlibat aktif dalam kegiatan belajarnya akan memiliki perolehan prestasi belajar lebih baik.

Berdasarkan uraian yang telah dijelaskan di atas membuktikan bahwa prestasi matematika siswa SMP di Indonesia masih tergolong rendah sedangkan self-regulated learning 
merupakan faktor yang sangat penting dalam perolehan prestasi matematika. Peneliti tertarik untuk mengangkat topik mengenai hubungan antara self-regulated learning dengan prestasi belajar matematika. Di dalam dunia psikologi pendidikan sebenarnya telah banyak penelitian yang membahas dan membuktikan teori mengenai self-regulated learning pada prestasi belajar matematika. Perbedaan penelitian ini dengan beberapa penelitian di atas terdapat pada tempat penelitian, subjek penelitian, proses pengambilan data, dan analisis data yang digunakan.

\section{Metode}

\section{Partisipan}

Subjek dalam penelitian ini adalah siswa kelas VIII SMP Negeri 1 Kasihan. Kriteria yang harus dimiliki subjek penelitian adalah siswa yang duduk di kelas VIII. Alasan penentuan kriteria ini karena siswa kelas VIII memiliki kegiatan yang cukup padat, yaitu selain ekstrakurikuler, kebanyakan dari mereka juga menjadi pengurus inti organisasi di sekolah. Padatnya kegiatan di sekolah tetap menuntut siswa untuk mengutamakan tugas-tugas yang diberikan oleh guru, terutama pelajaran matematika. Selain itu, secara psikologis siswa kelas VIII sudah bisa menyesuaikan dengan guru, teman, dan lingkungan sekolah.

\section{Pengukuran}

Prestasi belajar umumnya ditunjukkan dengan nilai rata-rata yang diperoleh siswa dari hasil belajar (Latifah, 2010). Nilai yang dihasilkan oleh siswa diukur atau dinilai menggunakan suatu tes Menurut Azwar (2011) dalam kegiatan pendidikan formal di kelas, tes prestasi belajar dapat berbentuk ulangan-ulangan harian, tes formatif, tes sumatif, bahkan Ujian Nasional (UN) dan ujian masuk perguruan tinggi. Tes prestasi belajar hanya memusatkan pada aspek kognitif (Azwar, 2011). Menurut Bloom (dalam Krathwohl, 2002) terdapat enam tahapan dalam aspek kognitif, yaitu mengingat, memahami, menerapkan, analisis, evaluasi, dan menciptakan.

Pada penelitian ini, prestasi belajar matematika siswa diukur berdasarkan hasil tes formatif yang diambil dari nilai UTS matematika semester satu siswa kelas VIII tahun ajaran 2016/2017. Soal berjumlah 40 dan berbentuk pilihan ganda dengan pilihan jawaban yang tersedia yaitu pilihan, a, b, c, d. Soal dibuat berdasarkan kompetensi dasar kelas VIII pertengahan semester satu yang ditulis pada Kurikulum 2013 (Kemendikbud, 2013). Soal tes matematika tingkat SMP lebih menekankan pada tahap mengingat, memahami, dan penerapan.

Tes ini memuat empat kompetensi dasar yang harus dicapai siswa kelas VIII pada pertengahan semester satu, yaitu menerapkan operasi aljabar, menentukan gradient persamaan dari grafik garis lurus, menyajikan fungsi dalam berbagai bentuk relasi, pasangan berurut rumus fungsi, tabel, grafik, diagram, dan menerapkan lokasi benda dalam koordinat Kartesius dalam menjelaskan posisi relatif terhadap acuan tertentu. Setiap kompetensi dasar memiliki jumlah soal yang relatif sama.

Self-Regulated Learning (SRL) dalam penelitian ini diukur menggunakan skala. Skala adalah ukuran gabungan untuk suatu variabel yang disusun atas dasar penunjukkan skor pada pola-pola atribut, artinya penyusunan skala harus memperhatikan intensitas struktur dari atribut-atribut yang hendak diukur (Effendi, 2012). Jenis skala yang digunakan dalam penelitian ini adalah skala Likert. 
Cara pengukurannya adalah subjek dihadapkan dengan sebuah pernyataan dan kemudian memintanya memberikan jawaban dalam lima pilihan jawaban yang memungkinkan mendekati gambaran mengenai dirinya, mulai dari Sangat Tidak Setuju (STS), Tidak Setuju (TS), Netral (N), Setuju (S), hingga Sangat Setuju (SS). Jawaban-jawaban ini diberi skor 1 sampai 5 (Effendi, 2012).

Skala dalam penelitian ini terdiri dari 44 aitem. Aitem dalam skala selfregulated learning dibuat berdasarkan komponen yang diungkapkan oleh Zimmerman (1989). Ada tiga komponen self-regulated learning yang diungkapkan oleh Zimmerman (1989), yaitu metakognisi, motivasi, dan strategi belajar. Metakognisi terdiri dari perencanaan, pemantauan, dan regulasi belajar. Motivasi terdiri dari persepsi diri, persistensi, dan goal setting. Strategi belajar dibedakan menjadi dua, yaitu strategi belajar kognitif yang terdiri dari pengulangan, elaborasi, organisasi dan strategi manajemen sumber daya yang terdiri dari mengatur dan mengontrol lingkungan belajar dan mencari bantuan termasuk guru dan teman.

Penyekoran dilakukan dengan cara memberi skor terendah pada pilihan jawaban sangat tidak sesuai dan memberi skor tertinggi pada pilihan jawaban sangat sesuai. Pernyataan yang ada di dalam skala mengandung pernyataan yang favorable, maka penyekorannya, yaitu bagi responden yang menjawab sangat sesuai 5 , sesuai - 4, netral - 3, tidak sesuai - 2 , sangat tidak sesuai -1 . Semakin tinggi skor yang diperoleh subjek dalam skor total, maka semakin tinggi self-regulated learning subjek. Sebaliknya, semakin rendah skor yang diperoleh subjek, maka semakin rendah pula self-regulated learning subjek.

\section{Metode analisis data}

Metode analisis data menggunakan teknik korelasi product moment dari Karl Pearson. Teknik ini digunakan untuk menguji hipotesis hubungan antara variabel selfregulated learning dengan variabel prestasi belajar matematika. Alasan menggunakan teknik korelasi product moment ini karena jenis data pada kedua variabel adalah interval atau berwujud skor (Jackson, 2003). Analisis data dalam penelitian ini menggunakan bantuan software IBM SPSS 16.0 for Windows.

Tabel 1

Deskripsi data penelitian

\begin{tabular}{clccccc}
\hline No. & \multicolumn{1}{c}{ Variabel } & N & \multicolumn{4}{c}{ Empirik } \\
\hline & & & Min & Max & Mean & SD \\
\hline 1. & $\begin{array}{l}\text { Prestasi Belajar } \\
\text { Matematika } \\
\text { 2. }\end{array}$ & 129 & 35 & 100 & 74,96 & 13,26 \\
\hline $\begin{array}{l}\text { Self-Regulated Learning } \\
\text { 2 }\end{array}$ & 129 & 111 & 202 & 155,18 & 18,18 \\
\hline
\end{tabular}

Tabel 2

Deskripsi kategorisasi skor self-regulated learning

\begin{tabular}{|c|c|c|c|c|}
\hline Norma & Kategori & Interval & Frekuensi & $\%$ \\
\hline $\mathrm{X} \leq \mathrm{M}-1 \mathrm{SD}$ & Rendah & $X \leq 136,99$ & 22 & 17,05 \\
\hline $\mathrm{M}-1 \mathrm{SD}<\mathrm{X} \leq \mathrm{M}+1 \mathrm{SD}$ & Sedang & $136,966<X \leq 173,36$ & 84 & 65,12 \\
\hline$M+1 S D<X$ & Tinggi & $177,36<X$ & 23 & 17,83 \\
\hline JUMLAH & & & & $129 \quad 100$ \\
\hline
\end{tabular}




\section{Hasil}

\section{Deskripsi data}

Tujuan deskripsi data penelitian adalah untuk memberikan gambaran mengenai keadaan distribusi skor skala pada kelompok subjek yang dikenai pengukuran, sehingga dapat memberikan informasi serta gambaran mengenai keadaan subjek pada variabel yang diteliti (Azwar, 2007). Cara mengetahui skor empirik dilakukan dengan menggunakkan IBM SPSS 16.0 for Windows. Deskripsi data penelitian dapat dilihat pada Tabel 1 . Variabel self-regulated learning dikategorikan berdasarkan pada skor empirik subjek penelitian. Subjek akan dikategorisasikan ke dalam tiga kelompok, yaitu rendah, sedang, dan tinggi. Kategori rendah dihitung dengan ketentuan rumus $\mathrm{X} \leq \mathrm{M}-1$ SD. Kategori sedang dihitung dengan ketentuan rumus $\mathrm{M}-1 \mathrm{SD}<\mathrm{X} \leq$ $M+1$ SD. Kategori tinggi dengan ketentuan rumus $\mathrm{M}+1 \quad \mathrm{SD}<\mathrm{X}$. Hasil pengkategorisasian variabel self-regulated learning dapat dilihat pada Tabel 2.

Tabel 2 menunjukkan persebaran skor self-regulated learning. Berdasarkan kondisi di lapangan dengan subjek

keseluruhan 129, ada 22 siswa $(17,05 \%)$ termasuk kategori rendah, 84 siswa $(65,12 \%)$ termasuk kategori sedang, dan 23 siswa $(17,83 \%)$ termasuk kategori tinggi.

Pada variabel prestasi belajar matematika tidak menggunakan metode kategorisasi di atas, karena menurut kurikulum 2013 kategorisasi penilaian matematika sudah terdapat panduan yang telah ditetapkan (Kemendikbud, 2015). Berikut kategorisasi penilaian matematika menggunakan standar kurikulum 2013 dengan ketentuan:

Sangat Baik (A) : 86-100

Baik (B) : :71-85

Cukup (C) : :56-70

Kurang (D) : $\leq 55$

Tabel 3 menunjukkan persebaran prestasi belajar matematika subjek. Berdasarkan kondisi di lapangan dengan subjek keseluruhan sebanyak 129, ada 25 subjek (19,38\%) memiliki prestasi belajar matematika dalam kategori sangat baik, 58 subjek $(44,96 \%)$ termasuk kategori baik, 33 subjek $(25,38 \%)$ termasuk kategori cukup, dan 13 subjek (10,08\%) termasuk kategori kurang.

Tabel 3

Deskripsi kategorisasi prestasi belajar matematika

\begin{tabular}{lcc}
\multicolumn{1}{c}{ Kategori } & Jumlah siswa & Persen (\%) \\
\hline $\begin{array}{l}\text { Sangat Baik (A) } \\
(86-100)\end{array}$ & 25 & 19,38 \\
$\begin{array}{l}\text { Baik (B) } \\
(71-85)\end{array}$ & 58 & 44,96 \\
Cukup (C) & & \\
$\begin{array}{l}\text { (56-70) } \\
\text { Kurang (D) } \\
\leq 55\end{array}$ & 33 & 25,58 \\
\hline
\end{tabular}

Tabel 4

Hasil uji normalitas

\begin{tabular}{cccccc}
\hline No. & \multicolumn{1}{c}{ Variabel } & N & Nilai $Z_{K S}$ & $\mathbf{P}$ & Keterangan \\
\hline 1. & Prestasi Belajar Matematika & 129 & 1,114 & 0,167 & Normal \\
\hline 2. & Self-Regulated Learning & 129 & 0,636 & 0,814 & Normal \\
\hline
\end{tabular}


Uji asumsi dilakukan sebelum pengujian hipotesis. Data penelitian yang ada harus memenuhi dua syarat yaitu uji normalitas dan uji linearitas untuk bisa menggunakkan analisis product moment. Hal ini dilakukan untuk mengetahui apakah data penelitian yang ada layak atau tidak apabila dianalisis menggunakan analisis product moment dari Pearson. Kedua pengujian dilakukan menggunakkan IBM SPSS 16.0 for Windows. Berikut pengertian dari uji normalitas dan uji linearitas.

Uji normalitas dalam penelitian ini menggunakan teknik KolmogorovSmirnov (Zкs) pada IBM SPSS 16.0 for Windows. Hal ini bertujuan untuk mengetahui apakah data penelitian yang ada sudah terdistribusi secara normal atau tidak. Data penelitian dikatakan terdistribusi secara normal apabila taraf signifikansi nilai $p>0,05$, sedangkan $p<$ 0,05 maka data dikatakan tidak terdistribusi secara normal. Berikut hasil uji normalitas pada variabel self-regulated learning dan prestasi belajar matematika.

Berdasarkan Tabel 4, dapat dilihat bahwa hasil pengukuran variabel prestasi belajar matematika pada 129 subjek menunjukkan nilai koefisien KolmogorovSmirnov Z (ZKs) sebesar 1,114 dengan $p=$ 0,167 $(p>0,05)$, sehingga dapat dikatakan bahwa data terdistribusi secara normal. Variabel self-regulated learning memiliki nilai koefisien Kolmogorov-Smirnov Z (Zкs) yaitu $0,636(p>0,05)$, sehingga dapat dikatakan bahwa terdistribusi secara normal. Berdasarkan hasil tersebut, dengan taraf signifikansi 5\% didapatkan kesimpulan bahwa kedua variabel tersebut terdistribusi secara normal (gagal tolak H0).

Selanjutnya, setelah melakukan uji normalitas, syarat uji asumsi selanjutnya adalah melakukan uji linearitas. Uji linearitas dilakukan untuk mengetahui apakah sebaran data dari kedua variabel penelitian mempunyai hubungan linear atau tidak. Pada penelitian ini, uji linearitas dilakukan dengan menggunakan metode test-for linearity pada IBM SPSS versi 16.0 for Windows. Syarat yang digunakan adalah $\mathrm{F}$ linearity. Jika $p<0,05$ maka hubungan linear, tetapi jika $p>0,05$ maka hubungan tidak linear. Tabel 5 merupakan hasil uji linearitas.

Berdasarkan Tabel 5, dapat diketahui bahwa diperoleh hasil F linearity sebesar 15,367, dengan $p<0,05$. Berdasarkan hasil tersebut, dapat disimpulkan bahwa antara self-regulated learning dengan prestasi belajar matematika terdapat hubungan yang linear.

Uji hipotesis menggunakan teknik korelasi product moment dari Pearson dapat dilakukan apabila data terdistribusi secara normal dan linear. Teknik korelasi product moment dari Pearson dalam penelitian ini digunakan untuk melihat hubungan antara self-regulated learning dengan prestasi belajar matematika. Hipotesis yang diajukan dalam penelitian ini adalah terdapat hubungan positif antara selfregulated learning dengan prestasi belajar matematika.

Tabel 5

Hasil uji linearitas

\begin{tabular}{lcccc}
\hline \multicolumn{1}{c}{ Variabel } & $\mathbf{F}$ & $\mathbf{P}$ & Syarat & Keterangan \\
\hline Linearity & 15,637 & 0,000 & $p<0,05$ & \\
$\begin{array}{l}\text { Deviation from } \\
\text { Linearity }\end{array}$ & 0,739 & 0,884 & $p>0,05$ & Linear \\
\hline
\end{tabular}


Sebelum menentukan hipotesis yang akan diterima atau ditolak maka harus ditetapkan sebuah parameter. Hipotesis dapat diterima dan signifikan apabila memiliki peluang kesalahan kurang dari $5 \%(p<0,05)$ dan hipotesis sangat signifikan apabila kesalahan kurang dari $1 \%(p<0,01)$. Dengan demikian hipotesis ditolak jika $p>0,05$. Angka koefisien korelasi terbesar positif adalah 1, dan angka koefisien korelasi terkecil adalah 0 .

Pada penelitian ini korelasi yang dihasilkan sebesar $r=0,351(p<0,01)$, atau dapat dikatakan sangat signifikan ( $\mathrm{H} 0$ ditolak). Berdasarkan hasil tersebut dapat disimpulkan bahwa ada hubungan positif dan signifikan antara self-regulated learning dengan prestasi belajar matematika pada siswa SMP.

Berdasarkan hasil uji hipotesis, maka hipotesis yang diajukan dalam penelitian ini, yaitu ada hubungan antara selfregulated learning dengan prestasi belajar matematika dapat diterima. Artinya, semakin tinggi self-regulated learning maka semakin tinggi prestasi belajar matematika, sebaliknya semakin rendah self-regulated learning maka semakin rendah prestasi belajar matematika.

\section{Diskusi}

Berdasarkan hasil analisis data yang telah dilakukan menunjukkan bahwa hipotesis yang menyatakan ada hubungan antara self-regulated learning dengan prestasi belajar matematika dapat diterima. Hal ini dibuktikan dengan nilai koefisien korelasi yang dihasilkan, yaitu $r=0,351(p<0,01)$, yang menunjukkan bahwa kedua variabel tersebut memiliki hubungan yang positif dan signifikan. Hal ini berarti, semakin tinggi self-regulated learning maka semakin tinggi prestasi belajar matematika, sebaliknya semakin rendah self-regulated learning maka semakin rendah prestasi belajar matematika. Diterimanya hipotesis tersebut menunjukkan bahwa ketika siswa SMP yang memiliki self-regulated learning tinggi akan memiliki prestasi belajar matematika yang tinggi.

Hasil penelitian ini mendukung penelitian Rosario, Nunez, Valle, Pienda, dan Lourenco (2013) yang menunjukkan bahwa ada hubungan positif antara siswa yang memiliki strategi self-regulated learning dengan prestasi belajar matematika. Siswa yang dapat mengorganisasikan, mengatur dan lebih mempersiapkan tugasnya, serta melakukan perencanaan belajarnya dengan baik akan memengaruhi perolehan prestasi matematikanya. Sebagaimana yang diungkapkan oleh Rosario, dkk. (2013) bahwa kesuksesan siswa di sekolah dapat dilihat dari bagaimana siswa tersebut belajar. Hal ini mendukung penelitian yang dilakukan oleh Zimmerman dan Martinez-Pons (1990) dan Pintrich dan De Groot (1990) menunjukkan bahwa siswa yang memiliki perencanaan, organisasional, dan memonitor diri dalam belajarnya akan berpengaruh terhadap prestasi akademiknya.

Penelitian lain yang dilakukan oleh Camahalan (2006) yang meneliti efek pelatihan self-regulated learning terhadap prestasi belajar matematika menunjukkan bahwa terdapat pengaruh yang signifikan pada kelompok yang diberi pelatihan selfregulated learning terhadap perolehan prestasi matematika. Siswa yang diberi pelatihan self-regulated learning mengaku ketika menemui soal yang sulit, ia tetap beusaha menyelesaikannya, sehingga dapat meningkatkan kemampuan matematika. Hal tersebut sesuai dengan yang diungkapkan oleh McComb (1989) bahwa siswa yang memilki persistensi 
dalam diri atau bertahan ketika gagal dan tidak mudah menyerah dalam menghadapi tugas yang sulit akan memiliki ketertarikan (motivasi intrinsik) dan menikmati tugasnya. Hal ini akan memengaruhi seseorang dalam penggunaan strategi self-regulated learning pada aktivitas belajarnya.

Hasil penelitian ini juga mendukung penelitian Isaacson dan Fujita (2006) yang menyebutkan bahwa self-regulated learning berkorelasi positif dengan kesuksesan seseorang dalam akademiknya. Siswa yang berprestasi tinggi melaporkan sering menggunakan strategi self-regulated learning dalam belajarnya. Penggunaan kemampuan regulasi metakognisi yang dapat membantu siswa dalam mengarahkan, mengatur dan memantau proses belajarnya, menentukan tujuan belajarnya, membantu melakukan penilaian terhadap tugas belajarnya. Siswa yang kurang bisa menggunakan kemampuan regulasi metakognisi akan berpengaruh terhadap prestasi belajar matematika. Penelitian ini juga menemukan bahwa siswa yang dapat menggunakan feedback berasal dari hasil tes atau ujian akan membantu mereka dalam memperbaiki tujuan belajarnya berdasarkan feedback tersebut. Menurut Pintrich (1999) perilaku tersebut diartikan sebagai strategi regulasi. Strategi regulasi dapat membantu siswa untuk merencanakan belajarnya, memilih strategi belajar yang tepat serta mengevaluasinya, guna meningkatkan prestasi belajarnya.

Penelitian lain dilakukan oleh Khatib (2010) mengenai hubungan antara selfregulated learning dan motivational beliefs pada prestasi akademik pelajar di United Arab Emirates (UAE) menunjukkan bahwa ada hubungan positif antara kedua variabel tersebut dengan prestasi akademik. Menurut penelitian Khatib (2010) siswa yang memiliki motivasi intrinsik berupa memiliki sikap positif, memilih tugas yang menantang, memiliki kecemasan yang lebih rendah, dan memiliki ketakutan yang lebih rendah akan berpengaruh terhadap hasil prestasi akademiknya. Hal senada diungkapkan oleh McComb dan Whisler (1997) bahwa ketika siswa memilki motivasi intrinsik ia akan memiliki rasa ingin tahu atau ketertarikan dalam belajar dan akan menikmati proses belajarnya.

Hasil pengkategorisasian pada prestasi belajar matematika menunjukkan bahwa subjek dalam penelitian ini sebagian besar sudah memiliki prestasi belajar matematika yang baik yaitu sekitar $64 \%$. Namun, hasil kategorisasi prestasi belajar matematika juga memperlihatkan masih adanya siswa yang memiliki prestasi belajar matematika rendah, sekitar 36\% siswa yang masih di bawah KKM. Guru matematika menyatakan bahwa siswa yang memiliki prestasi belajar matematika rendah tersebut kecenderungan karena kurang memperhatikan guru saat proses belajar matematika di kelas, ramai sendiri saat di kelas, dan kurang bisa mengendalikan diri pada saat proses belajar matematika. Hal ini mendukung hasil penelitian bahwa siswa yang memiliki self-regulated learning yang baik akan memperoleh prestasi belajar matematika yang optimal.

Hasil penelitian ini memperlihatkan bahwa kedua variabel menunjukkan korelasi rendah yang ditunjukkan dengan $r=0,351$. Hal ini menandakan bahwa ada banyak faktor internal lain ataupun eksternal di luar self-regulated learning yang ikut memengaruhi pencapaian prestasi belajar matematika siswa SMP. Berdasarkan karakteristik mata pelajaran matematika, Alsa (2005) menyatakan bahwa faktor-faktor internal yang lebih dapat memengaruhi prestasi belajar matematika adalah faktor inteligensi, bakat matematika, minat matematika, sikap terhadap pelajaran matematika, dan 
motivasi mempelajari matematika. Faktor eksternal yang memengaruhi prestasi belajar matematika adalah dukungan sosial (Khaliq, 2015). Faktor eksternal lain yang berpengaruh pada prestasi belajar matematika adalah guru matematika yang berkualitas, dapat menyampaikan materi dengan jelas, mampu memotivasi siswa di kelas memiliki korelasi positif dengan sikap siswa terhadap pelajaran matematika (Peter, 2013).

Berdasarkan uraian di atas, dapat disimpulkan bahwa self-regulated learning memiliki hubungan yang positif terhadap prestasi belajar. Siswa yang memiliki perilaku belajar aktif serta dapat mengatur, mengendalikan, dan memonitor belajarnya akan memiliki prestasi matematika yang baik. Hasil korelasi menunjukkan adanya hubungan yang lemah antara self-regulated learning dengan prestasi belajar matematika, sehingga kemungkinan terdapat banyak faktor lain yang memengaruhi prestasi belajar matematika siswa SMP.

Hasil penelitian ini menunjukkan bahwa ada hubungan positif yang signifikan antara self-regulated learning dengan prestasi belajar matematika pada siswa SMP. Hal ini dapat dilihat berdasarkan hasil analisis korelasi product moment bahwa koefisien korelasi antara self-regulated learning dengan prestasi belajar matematika siswa sebesar $r=0,351$, $p<0,001$. Berdasarkan hasil tersebut, dapat disimpulkan bahwa terdapat hubungan yang positif dan signifikan antara selfregulated learning dengan prestasi belajar matematika. Semakin tinggi self-regulated learning, maka semakin tinggi prestasi belajar matematika, begitu pun sebaliknya semakin rendah self-regulated learning maka semakin rendah pula prestasi belajar matematika.

\section{Kesimpulan}

Hasil penelitian ini menunjukkan bahwa ada hubungan positif yang signifikan antara self-regulated learning dengan prestasi belajar matematika pada siswa SMP. Hal ini dapat dilihat berdasarkan hasil analisis korelasi product moment bahwa koefisien korelasi antara selfregulated learning dengan prestasi belajar matematika siswa sebesar $r=0,351, p<$ 0,001 . Berdasarkan hasil tersebut, dapat disimpulkan bahwa terdapat hubungan yang positif dan signifikan antara selfregulated learning dengan prestasi belajar matematika. Semakin tinggi self-regulated learning, maka semakin tinggi prestasi belajar matematika, begitu pun sebaliknya semakin rendah self-regulated learning maka semakin rendah pula prestasi belajar matematika.

\section{Saran}

Self-regulated learning dengan prestasi belajar matematika dalam penelitian ini memperlihatkan hubungan yang positif dan signifikan. Oleh karena itu hasil penelitian ini dapat memberi masukan kepada siswa khususnya dalam belajar matematika untuk aktif mengatur dan merencanakan perilaku belajarnya, antara lain dengan menetapkan tujuan dalam belajar matematika, menggunakan strategi belajar yang sesuai, dan mencari bantuan teman atau guru ketika mengalami kesulitan mempelajari matematika. Selain itu, prestasi belajar matematika di Indonesia masih rendah terlebih apabila dibandingkan dengan negara-negara di dunia yang mengikuti survey TIMSS dan PISA (Kemdikbud, 2013). Oleh karena itu sangat diperlukan perhatian dan penelitian mengenai hal ini. Self-regulated learning penting dalam meningkatkan perolehan prestasi belajar matematika 
siswa SMP, sehingga perlu ditingkatkan. Upaya yang dapat dilakukan sekolah antara lain dengan memberikan pelatihan strategi self-regulated learning pada siswa seperti dalam penelitian yang dilakukan oleh Hani (2010). Self-regulated learning dengan prestasi belajar matematika dalam penelitian ini memiliki korelasi sebesar 0,351, artinya banyak faktor lain yang memengaruhinya. Bagi peneliti selanjutnya yang mengangkat tema dengan permasalahan prestasi belajar matematika dapat mengkaji lebih lanjut mengenai variabel lain yang dapat memberikan sumbangan besar dalam meningkatkan prestasi belajar matematika. Beberapa contoh faktor yang dapat memengaruhi prestasi belajar matematika seperti minat dan sikap terhadap pelajaran matematika, dapat juga mengkaji dari faktor eksternal siswa, seperti dukungan sosial dan metode pembelajaran.

\section{Kepustakaan}

Ahmed, W., Werf, G. V. D., Kuyper, H., \& Minnaert, A. (2013). Emotions, selfregulated learning, and achievement in mathematics: A growth curve analysis. Journal of Educational Psychology, 105(1), 150-161.

Alsa, A. (2005). Program belajar, jenis kelamin, belajar berdasar regulasi diri dan prestasi belajar matematika pada pelajar SMA Negeri di Yogyakarta. Disertasi. Fakultas Psikologi Universitas Gadjah Mada, Yogyakarta.

Anna, L. K. (2012, Juni). Banyak siswa tak lulus ujian matematika. Kompas. Diakses dari http://edukasi.kompas.com/ tanggal 20 Agustus 2016.

Armanto, D. (2002). Teaching multiplication realistically in Indonesian elementary schools. Disertasi. Utrecht University, Utrecht.
Azwar, S. (2011). Tes prestasi: Fungsi dan pengembangan pengukuran prestasi belajar (Edisi II). Yogyakarta: Pustaka Pelajar.

Azwar, S. (2007). Metode penelitian. Yogyakarta: Pustaka Pelajar.

Camahalan, F. M. G. (2006). Effects of selfregulated learning on mathematics achievement of selected Southeast Asian Children. Journal of Instructional Psychology, 33(3), 194205.

Effendi, S. (2012). Metode penelitian survei. Jakarta: LP3S.

Isaacson, R. M., \& Fujita, A. (2006). Metacognitive knowledge monitoring and self-regulated learning: Academic succes and reflections on learning. Journal of the Scholarship of Teaching and Learning, 6(1), 39-55.

Hamdu, A., \& Agustina, L. (2011). Pengaruh motivasi belajar siswa terhadap prestasi belajar IPA di Sekolah Dasar. Jurnal Penelitian Pendidikan, 12(1), 1-7.

Hani, A. R. (2010). Efektivitas pelatihan belajar berdasar regulasi diri untuk meningkatkan prestasi belajar matematika pada siswa SMP. Tesis. Fakultas Psikologi Universitas Gadjah Mada, Yogyakarta.

Jackson, S. L. (2003). Research methods and statistics: A critical thinking approach.

Belmont: Wadsworth.

Kemendikbud. (2013). Kurikulum 2013: Kompetensi dasar SMP/MTs. Jakarta: Kementrian Pendidikan dan Kebudayaan, 2013.

Kemendikbud. (2015). Panduan penilaian untuk Sekolah Menengah Pertama (SMP). Jakarta: Kementrian Pendidikan dan Kebudayaan, 2015.

Khaliq, I. (2015). Belajar berdasar regulasi diri dan dukungan sosial sebagai prediktor prestasi belajar matematika pada siswa SMK. Tesis. 
Fakultas Psikologi Universitas Gadjah Mada, Yogyakarta.

Khatib, S. A. (2010). Meta-cognitive selfregulated learning and motivational beliefs as predictors of college students' performance. International Journal for Research in Education (IJRE). 27(1), 1-16.

Kleden, M. A. (2016). Mengapa harus belajar matematika?. Tribunnews. Diakses dari http://kupang.tribunnews.com/2016/ 03/03/mengapa-harus-belajarmatematika tanggal 12 Mei 2016.

Krathwohl, D. R. (2002). A revision of Bloom's taxonomy: An overview. Theory into Practice, 41(4), 212-218.

Latifah, E. (2010). Strategi self-regulated learning dan prestasi belajar: Kajian meta analisis. Jurnal Psikologi, 37(1), 110-129.

McComb, B. L., \& Whisler, J. S. (1997). The learner-centered classroom and school. San Fransisco: Jossey-Bass Publishers.

McComb, B. L. (1989). Self-regulated learning and academic achievement: A phenomenological view. In B. J. Zimmerman, \& D. H. Schunk, Selfregulated learning and academic achievement: Theory, research, and practice. (pp. 51-82). New York: Springer-Verlag, Inc.

Montalvo, F. T., \& Torrez, M. C. G. (2004). Self-regulated learning: Current and future directions. Electronic Journal of Research in Educational Psychology, 134.

NCES. (2011). Timss table. National Center for Education Statistics. Diakses dari http://nces.ed.gov/survey/timss tanggal 11 Mei 2016.

Permendiknas. (2015). Penetapan Kriteria Kentuntasan Minimal (KKM). Jakarta:
Peraturan Pemerintah Pendidikan Nasional.

Peter, D. O. (2013). School variables and senior secondary students achievement in mathematics in river State Nigeria. Mediterranean Journal of Social Sciences, 4(2), 709-718.

Pintrich, P. R \& De Groot. (1990). Motivational and self-regulated learning components of classroom academic performance. Journal of Educational Psychology, 82(1), 33-40.

Pintrich, P. R. (1999). The role of motivation in promoting and sustaining self-regulated learning. International Journal of Educational Research, 31(1), 459-470.

Pintrich, P. R. (2000). The role of goal orientation in self-regulated learning. In M. Boekaerts, P. R. Pintrich, \& M. Zeidner (Eds.), Handbook of self-regulation (pp. 451494). San Diego: Academic.

Pukan, B. (2015). Hasil UN SMP tahun ini menurun. NTTSatu. Diakses dari http://www.nttsatu.com/hasil-unsmp-tahun-ini-menurun/ tanggal 04 Agutus 2016.

Rahmawati. (2016). Seminar hasil TIMSS 2015. Puspendik. Diakses dari http://puspendik.kemdikbud.go.id/s eminar/ tanggal 04 Agutus 2016.

Rosario, P., Nunez, J. C., Valle, A., Pienda, J. G., Lourenco, A. (2013). Grade level, study time, and grade retention and their effects on motivation, self-regulated learning strategies, and mathematics achievement; A structural equation model. European Journal of Psychology of Education. 28, 1311-1331.

Uno, H. B. (2009). Teori motivasi dan pengukurannya. Jakarta, Bumi Aksara. 
Wager, A. A. (2013). Practices that support mathematics learning in a playbased classroom. In L. D. English \& J. T. Mulligan (Eds.). Reconceptualizing early mathematics learning. (pp. 163-182). NewYork: Springer.

Wurinanda, I. (2016). Matematika paling sulit di UN smp 2016. Okezone. Diakses dari http://news.okezone.com/read/2016/ 06/10/65/1411853/matematikapaling-sulit-di-un-smp-2016 tanggal 3 Agustus 2016.

Zimmerman, B. J., \& Martinez-Pons, M. (1990). Student differences in selfregulated learning: Relating grade, sex, and giftedness to self efficacy and strategy use. Journal of Educational Psychology, 82(1), 51-59.

Zimmerman, B. J., \& Kitsantas (1999). Acquiring writing revision skill, shifting from process goals to outcome self regulatory goals. Journal of Educational Psychology, 91 (2), 241-250.

Zimmerman, B. J. (1990). Self-regulated learning and academic achievement: An overview. Educational Psychologist, 25(1), 3-17. doi: 10.1207/s15326985ep2501_2.

Zimmerman, B. J. \& Schunk, D. H (1989). Self-regulated learning and academic achievement. New York, Springer. doi; 10.1007/978-1-4612-3618-4.

Zimmerman, B. J. (1989). A social cognitive view of self-regulated learning. Journal of Educational, 81(3), 329-339.

Zimmerman, B. J., \& Schunk, D. H. (2004). Self-regulating intellectual processes and outcomes: A social cognitive perspective. Upper Saddle River, NJ: Erlbaum.

Zimmerman, B. J., (2008). Investigating self-regulation and motivation: Historical background, methodological, developments, and future prospects. American Educational research Journal, 45(1), 166-183. 